\title{
Scholars and Literati at the University of Valence $(1452-1793)$
}

\author{
David de la Croix \\ IRES/LIDAM, UCLouvain
}

\author{
Alice Fabre \\ AMSE, Marseille
}

This note is a summary description of the set of scholars and literati who taught at the University of Valence (France) from its inception in 1452 to its abolishment during the French Revolution in 1793.

\section{The UnIVERSITY}

The University of Valence was founded in 1452, thanks to the pugnacity of the city's consuls (aldermen) and the will of the French Dauphin Louis, future Louis XI, who liked to stay in the region. In its early days, the university recruited several law professors from Italy. It reached its golden age in the 16th century, thanks to eminent jurists, like Cujas, who specialized in civil law and legal humanism, while being strongly shaken by outbreaks of plague and the religious wars; Valence was one of the first French centers of Calvinism. In 1565, it absorbed the neighboring rival university, located in Grenoble, but ended up declining, due to conflicts, and a lack of means and attractiveness, while training local jurists and trying to attract famous professors, mainly in law. "The abolition of the university in 1793 only confirmed its current state of affairs." (Guénée 1981)

\section{SOURCES}

The main source is Nadal (1861), which traces the history of the university since its creation, based on remaining archival documents. Two important bibliographic complements are the Dictionnaire biographique du département de la Drôme by Brun-Durand (1900), a biographical dictionary in two volumes which provides the portraits of illustrious individuals, mainly born in the department, and the historical dictionary of French jurists (12th-20th centuries) by Arabeyre, Halpérin, and Krynen (2007).

\section{SOME STATISTICs}

Table 1 shows some descriptive statistics. There are 230 scholars and literati. The year of birth is known for $26.1 \%$ of them. The mean age at nomination is 37.7 years; this relatively high age can be explained by the recruitment of already renowned professors at Valence, but also by some biases (insufficient records for unknown professors, lost footprint of scholars who died young). Longevity (mean age at death \& expected age at death when 30) is relatively high, except for the 16th century, a period of many wars and diseases. The birth place is known for only $37.8 \%$ of the individuals. This proportion declines over time, showing that the later professors are less known than the earlier ones. The median distance between birth and Valence is $71 \mathrm{~km}$, meaning that more than half of the scholars came from the region; this median varies considerably according to the period. Finally, $12.2 \%$ of the scholars have a Wikipedia page (in some language), and $22.2 \%$ of them have left a footprint in the catalogues of the libraries of the world, Worldcat, either by having published some work, or by having been the subject of published books and articles, with $22.8 \%$ in law, $22.2 \%$ in the humanities, and $24.2 \%$ in medicine. 


\begin{tabular}{|c|c|c|c|c|c|c|}
\hline \multicolumn{2}{|c|}{ Period } & nb. & $\%$ birth year & mean age & mean age & exp. age \\
\hline Start & End & obs & known & at nomin. & at death & at death \\
\hline 1450 & 1526 & 23 & 13 & 48 & 68.3 & 75.5 \\
\hline 1527 & 1617 & 66 & 37.9 & 35.7 & 62.2 & 62.8 \\
\hline 1618 & 1685 & 41 & 24.4 & 39.2 & 72.1 & 72.1 \\
\hline 1686 & 1733 & 44 & 15.9 & 39.1 & 75.2 & 76.2 \\
\hline 1734 & 1800 & 56 & 26.8 & 37.6 & 70.4 & 72.1 \\
\hline 1200 & 1800 & 230 & 26.1 & 37.7 & $\overline{67 . \overline{3}}$ & 67.1 \\
\hline & & & $\%$ birth place & median distance & $\%$ with & $\%$ with \\
\hline & & & known & birth-institution & Wikipedia & Worldcat \\
\hline 1450 & 1526 & & 52.2 & 315 & 4.3 & 21.7 \\
\hline 1527 & 1617 & & 59.1 & 80 & 24.2 & 40.9 \\
\hline 1618 & 1685 & & 36.6 & 0 & 7.3 & 22 \\
\hline 1686 & 1733 & & 15.9 & 235 & 6.8 & 4.5 \\
\hline 1734 & 1800 & & 25 & 32 & 8.9 & 14.3 \\
\hline 1000 & 1800 & & $3 \overline{7} . \overline{8}$ & $\overline{7} \overline{1}$ & $\overline{1} \overline{2} . \overline{2}$ & 22.2 \\
\hline
\end{tabular}

Table 1: Summary statistics by period

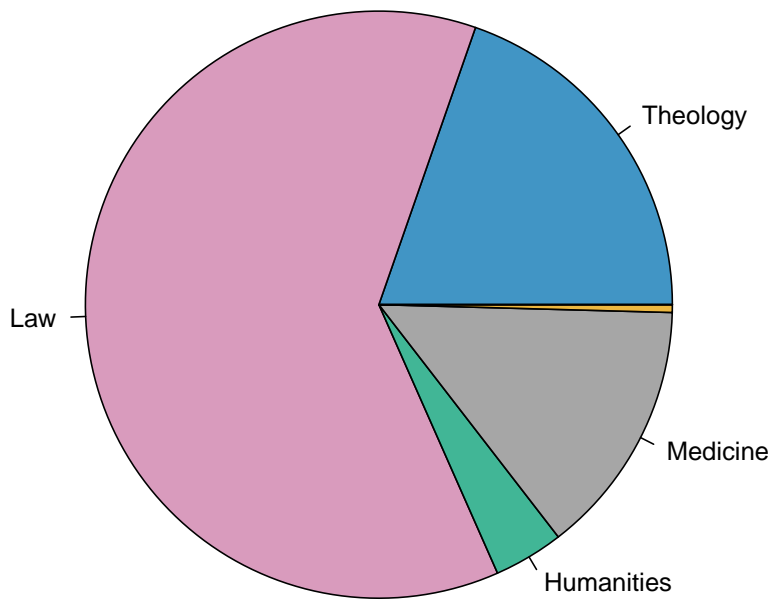

Figure 1: Broad fields at Valence 


\section{FIELDS}

Figure 1 shows the relative importance of fields, broadly defined. The university owes its reputation mainly to its famous jurists, like J. Cujas, who were hired with high wages. A second field was medicine, with professors who had graduated mainly from Montpellier. In the 18th century, the university experienced a small revival of its theological teaching. The first chair in mathematics was founded in 1784 .

\section{Place of Birth}

Figure 2 is a plot of the places of birth of all the scholars of Valence. It shows that there are not many observations with identified birth places, despite the existence of detailed secondary sources. It also shows the Italian contribution at the inception of the university.

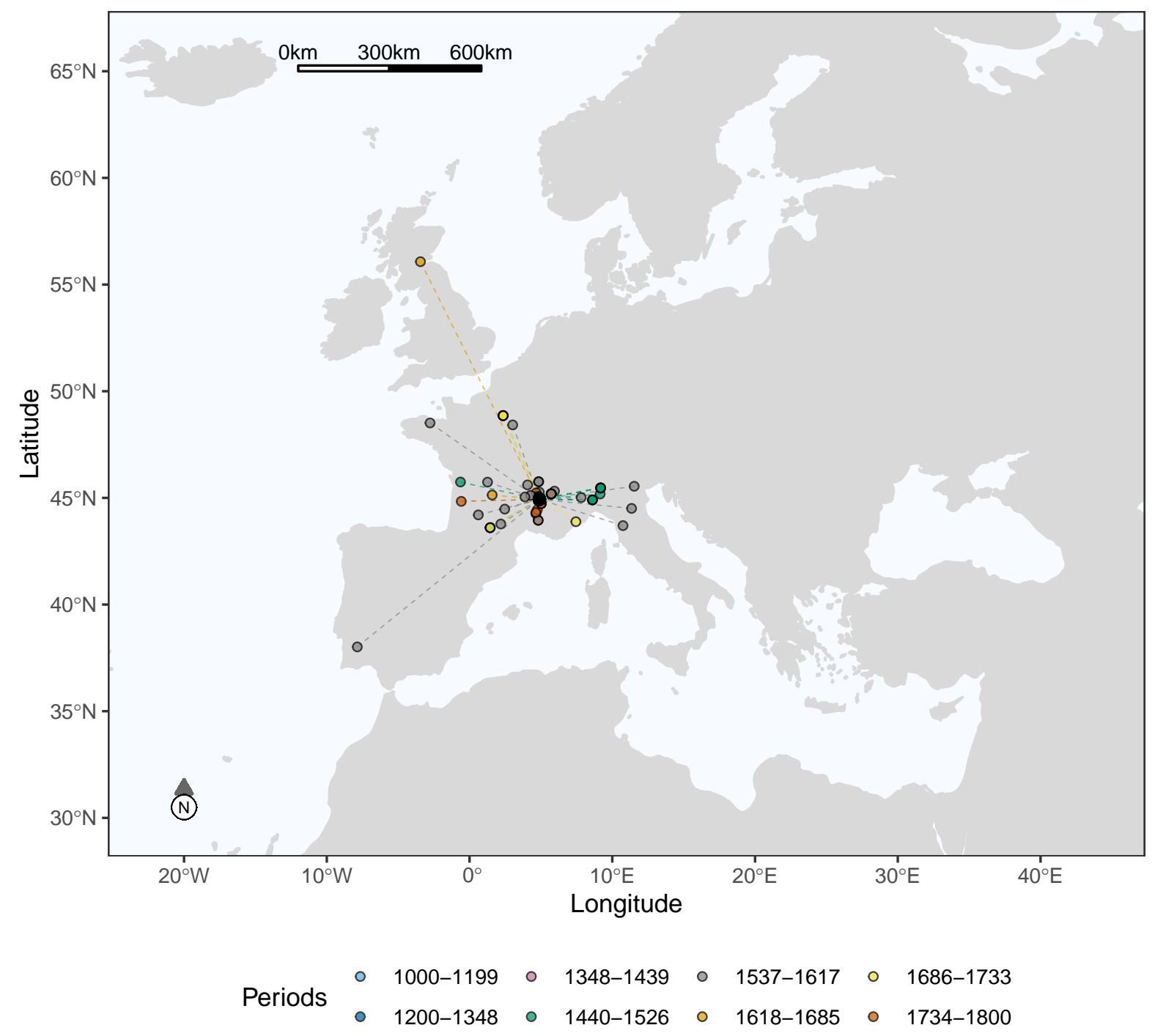

Figure 2: Place of birth of the scholars and literati at the University of Valence 


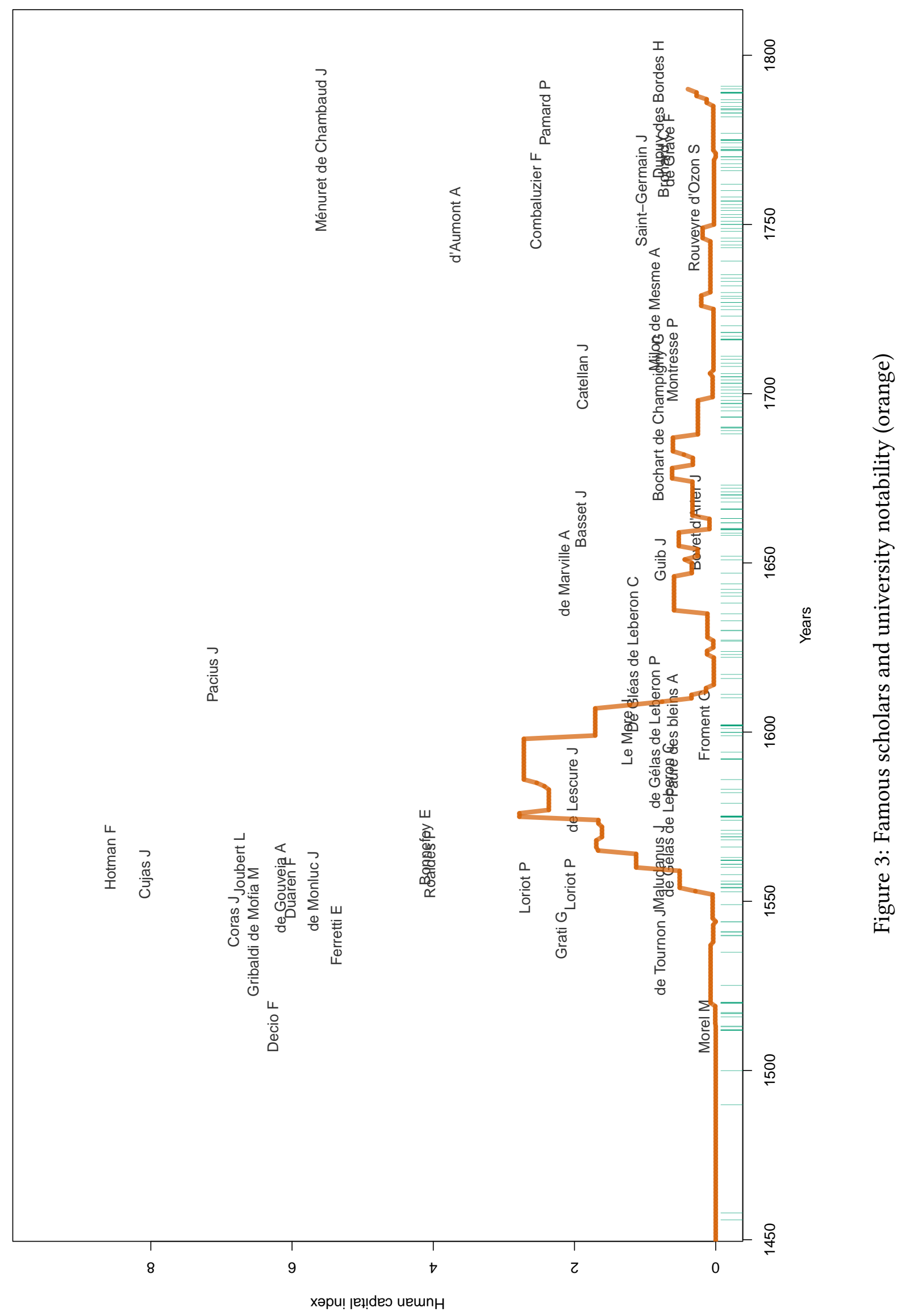




\section{HUMAN CAPITAL OF SCHOLARS AND LITERATI}

For each person in the database we compute a heuristic human capital index, identified by combining information from Worldcat and Wikipedia using a principal component analysis. We also compute the notability of the university at each date by averaging the human capital of the scholars active in Valence 25 years before that date. Details are given in the Appendix. Figure 3 shows the names of all the scholars with a positive human capital index. The orange line plots the notability of the university.

Valence clearly experienced a golden age in the 16th century, thanks to the influence of its school of civil law, and declined in the following centuries, with a slight revival in the 18th century, linked to a few scholars in medicine.

\section{TOP 5 PROFESSORS}

We now provide a brief overview of the five professors with the highest human capital index.

François Hotman (Paris 1524 - Balsen 1590). A professor of Roman law who graduated from Orléans, he left Paris for Switzerland, after converting to Calvinism, of which he was an ardent defender. In 1563, he came to teach law at the University of Valence, where he was highly esteemed and very prolific. For financial reasons, he left Valence for Bourges in 1567 and was replaced by Jacques Cujas. He went back into exile in Switzerland, shortly before the St. Bartholomew's Day massacre. He was the author of pamphlets against the Pope, and was also credited with different works that renewed the study of law, including Franco-Gallia (1573), a critique, in the light of history, of the absolutism of royal power. This work was one of the greatest bookstore successes of its time.

Jacques Cujas (Toulouse 1522 - Bourges 1590). A professor of civil law who graduated from Toulouse, he taught at Toulouse, Cahors, Bourges, Valence, Turin, and for one year Paris where he fled the reform in 1576, before going back to Bourges. He is considered to be one of the greatest humanists among French jurists, and his works (in particular his collection of Justinian manuscripts) are still useful today for studies in Roman law. He was replaced at Valence by Jules Pacius.

Jules Pacius (Vicenza 1550 - Valence 1635). A professor of Roman law, a Protestant, a follower of François Hotman, and an admirer of Jacques Cujas, he taught legal humanism at Geneva, Hungary, Heidelberg, Nîmes, Montpellier, Valence, and Padua. In Valence, he renounced Protestantism in his old age. He was well known by this time and was offered chairs in Italy and Holland, but decided to stay in Valence with his family.

Jean de Coras (Realmont (Tarn) 1515 - Toulouse 1572). A humanist and a professor of civil law, he was very well known and taught at Padua, Parma, Toulouse, Ferrara, Valence, Paris, Angers, Orléans. A notorious Calvinist, he was slaughtered during the St Bartholomew's Day massacre in Toulouse. In 1560, as a judge at the Parliament of Toulouse, he was involved in the Martin Guerre case, a judicial case of identity theft that garnered much attention at the time.

Laurent Joubert (1529 Valence - Lombers 1583). Born in Valence, he studied medicine at Montpellier, where he taught that subject almost during his entire career, although he also taught at Valence (1561-1567). He was renowned throughout Europe and also became the first physician to the French King Henry IV in 1579. He left many famous treatises, on the plague, pharmacopoeia, and laughter, as well as a writing dedicated to Queen Margot.

\section{RELATED SCHOLARS}

Beyond those who taught at Valence, several important individuals are related to the University. They probably did not occupy an official position, but they were involved in teaching and/or research. Here, we show the three related scholars with the highest human capital index. 
Joseph Juste Scaliger (Agen 1540 - Leiden 1609). Born of Catholic parents, he had apostasized by the age of 22. He came to Valence for three years in 1670 to study and debate with Jacques Cujas and to take advantage of his renowned library. Cujas is said to have helped him escape the St. Bartholomew's Day massacre in Valence in 1672. Known for his critical mind, he was a humanist and the author of historical treatises, numismatic works, collections of anecdotes, and above all an important correspondence, which gave him a solid reputation as a literary critic.

Jacques Auguste de Thou (Paris 1553 - Paris 1617). Born in Paris, he studied at several French universities, including Valence where he came to follow the teachings of Cujas, and studied with Scaliger. He left Valence just before St. Bartholomew's Day, and went on a long journey to Italy between 1572 and 1576. He sided with Henry IV. He was a poet and a historian who remains an appreciated bibliophile because of the exemplary library that he assembled, both in the choice of texts and bindings.

\section{FAMILIES OF SCHOLARS}

Many families from Valence produced lines of students and jurists, trained at the city's university, and hired by local jurisdictions. At least four created dynasties of law scholars (a father-son pair of professors teaching at Valence), including the Dorne family: Humbert de Dorne (1490), his son Antoine de Dorne (a scholar between 1520 and 1555), one of his sons Jean-Fortunat de Dorne (who failed against Antoine de Govea to obtain the first chair of law), and another son Pierre de Dorne, the Dean in 1594, whose daughter Isabelle married Antoine Faure des Bleins, a renowned professor at Valence, whose one child, a clergyman, became the vice-chancellor of the University of Valence. Figure 4 presents the genealogical tree of the Dorne family (from Geneanet), and highlights its members who taught (law) at Valence.

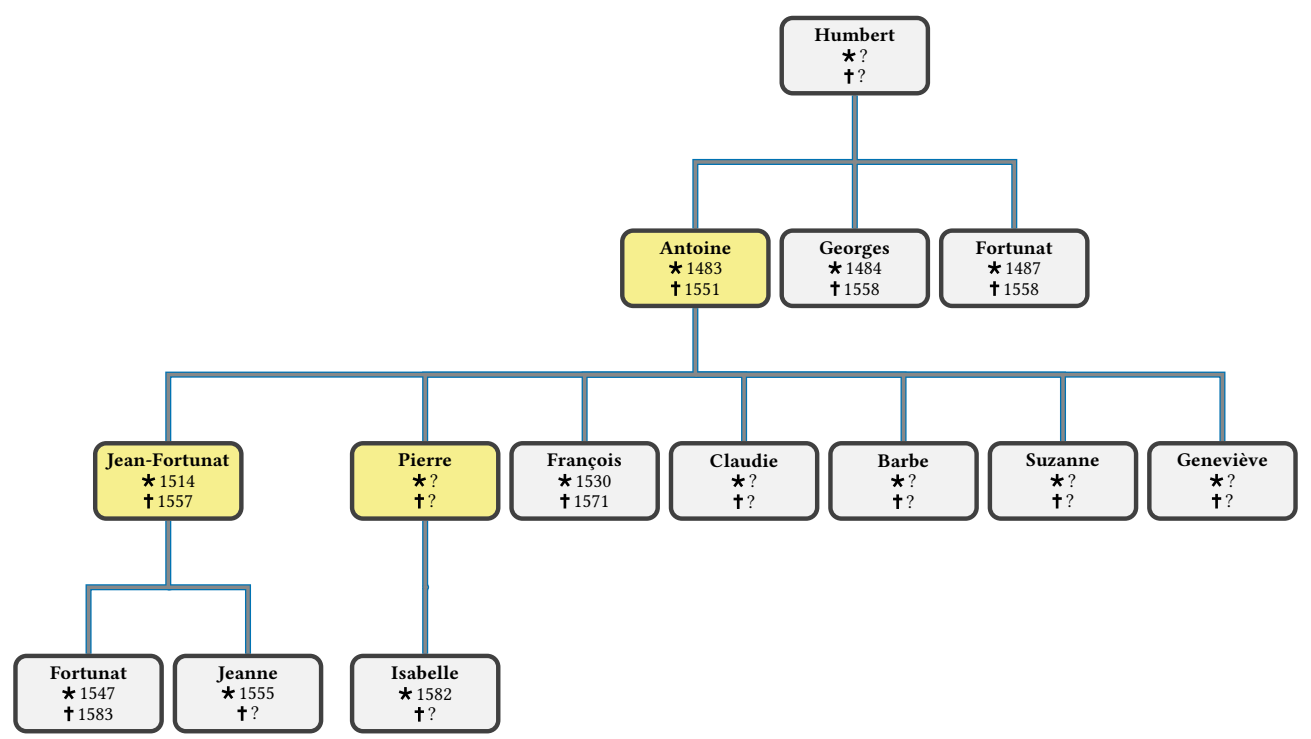

Figure 4: The "de Dorne" family. Professors at Valence in yellow squares

"This family is also remembered for the "Maison des Têtes", located 57 Grande Rue in the old city of Valence. It is a prime example of early 16th century architecture and a highlight of the city today. It was built between 1528 and 1532 by Antoine de Dorne. He decided on its construction after returning from a trip to Italy. On his death in 1551, the house passed to his son François, an adviser to the Dauphiné Parliament. 


\section{UNIVERSITY NETWORK}

Here, we assume that when a professor occupied a position at more than one university over his/her life, this established a link between those universities. The universities with which Valence is linked are displayed in Figure 5. The law professors at Valence, at least the most famous ones, were very often professors at Bourges, Toulouse, or Geneva, while those of medicine also taught at Montpellier.

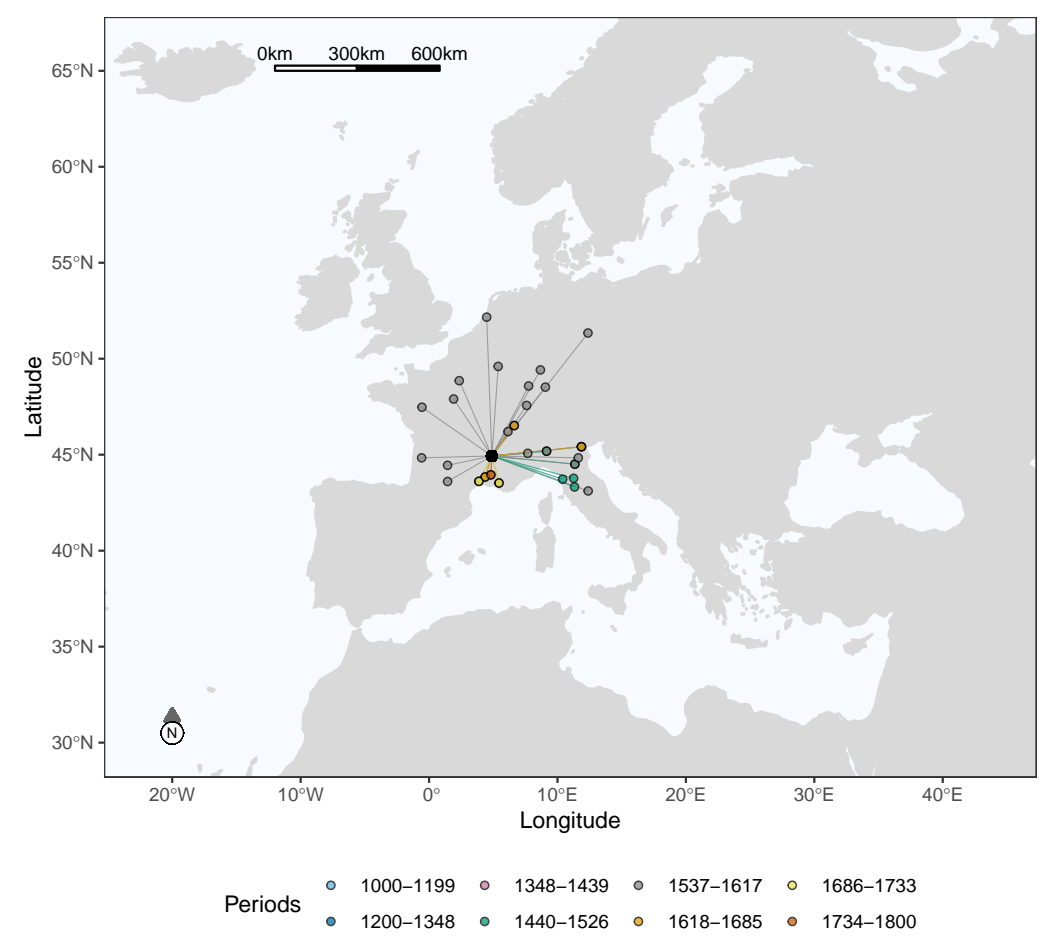

Figure 5: Links between Valence and other universities through scholars' mobility, by period

\section{ANECDOTES}

The role of the consuls of the city was considerable, especially in attracting renowned professors and finding resources to offer them appealing salaries. For instance, in 1574, depleted by the plague, religious wars, and famine, the coffers of the city and of the university were empty. Cujas asked for his pay and requested to be allowed to leave; the city went into debt and promised him new advantages. These negotiations show that a real academic market existed then. However, Cujas was tired of the situation and left for Bourges, as he may have thought - wrongly - that he would find a more peaceful city there.

In March 1788, in order to fill the vacant chair of philosophy at the University of Valence, a dialectic competition was organized, with five candidates pitted against each other for five days. Bonaparte, then a young artillery lieutenant, was part of the audience and is said to have coached Abbé Bosc, a candidate, providing him with many arguments and six cups of coffee (he allegedly insisted that the reluctant contestant should drink them, under the pretext that Voltaire drew his inspiration from the generous beverage). 


\section{APPENDIX}

The individual human capital index $q_{i}$ of an individual $i$ is given by:

$$
\begin{aligned}
q_{i}= & -1.76+0.43 \ln (\mathrm{nb} . \text { characters of the longest Wikipedia page }) \\
& +0.40 \ln (\text { nb. wikipedia pages in different languages })+0.47 \ln (\text { nb. works in Worldcat }) \\
& +0.46 \ln (\text { nb. publication languages in Worldcat })+0.47 \ln (\mathrm{nb} \text {. library holdings in Worldcat })
\end{aligned}
$$

We assume that having no Wikipedia page is similar to having one page with a length of 60 characters and that having no Worldcat page is similar to having a page with one work in one language held by one library. The constant -1.76 normalizes $q_{i}$ at 0 when there is neither a Wikipedia page, nor a Worldcat page. The weights $(0.43,0.40$, etc) are obtained from the first principal component of the five indicators (De la Croix et al. 2020).

The notability $Q$ of a university aggregates the $q$ of the top 5 persons who were active in the preceding 25 years using the following formula:

$$
Q=\sqrt{\sum_{i=1}^{5} \frac{1}{5}\left(\frac{q_{i}}{s_{i}}\right)^{2}}
$$

where $s_{i}$ is the number of universities in which $i$ had an appointment.

\section{ACKNOWLEDGMENTS}

This project has received funding from the European Research Council (ERC) under the European Union's Horizon 2020 research and innovation programme, under grant agreement No 883033 "Did elite human capital trigger the rise of the West? Insights from a new database of European scholars."

First version January 5, 2021. Updated October 9, 2021

\section{REFERENCES}

Arabeyre, Patrick, Jean-Louis Halpérin, and Jacques Krynen. 2007. Dictionnaire historique des juristes français (XIIe-XXe siècle). Paris: Presses Universitaires de France.

Brun-Durand, Justin. 1900. Dictionnaire biographique et biblio-iconographique de la Drôme, contenant des notices sur toutes les personnes de ce département qui se sont fait remarquer par leurs actions ou leurs travaux, avec l'indication de leurs ouvrages et de leurs portraits. Grenoble: H. Falque et F. Perrin.

De la Croix, David, Frédéric Docquier, Alice Fabre, and Robert Stelter. 2020. "The Academic Market and the Rise of Universities in Medieval and Early Modern Europe (1000-1800).” CEPR Discussion Paper 14509.

Guénée, Simone. 1981. Simone Guenée, Bibliographie des universités françaises des origines à la Révolution, Généralités-Université de Paris, 1981. Paris: Picard.

Nadal, Joseph Cyprien. 1861. Histoire de l'Université de Valence, et des autres établissements d'instruction de cette ville, etc. Valence: Impr. E. Marc Aurel. 